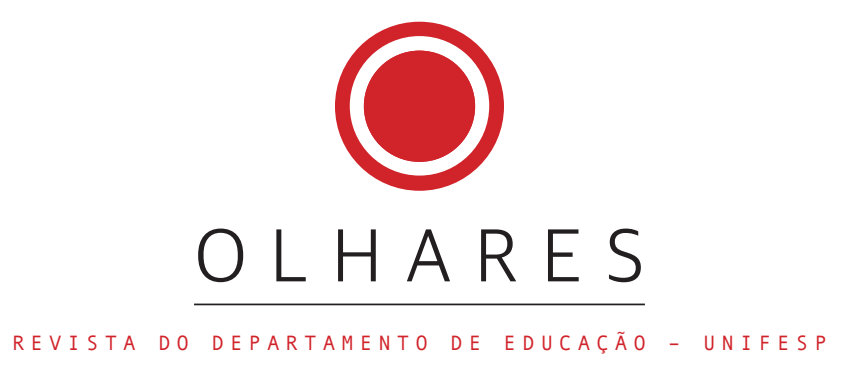

\author{
RESENHA / RESEÑA / REVIEW
}

CRUZ, Eliana Alves. O crime do cais do Valongo. Rio de Janeiro, Ed. Malê, 2018.

\title{
Retrato dos crimes da escravidão no Brasil
}

\section{Retrato de los crímenes de la esclavitud en Brasil}

\section{Portrait of slavery crimes in Brazil}

\author{
Meire Oliveira Silva \\ Docente Universidade Estadual do Oeste do Paraná (UNIOESTE) \\ meire_oliveira@uol.com.br
}

Num misto de relato histórico, jornalístico e ficcional, e a partir da consulta a arquivos de época, criatividade e largo conhecimento sobre o assunto em questão - o cotidiano no Brasil escravocrata do século XIX - um crime é descrito. Trata-se do assassinato de Bernardo Lourenço Viana, "conhecido comerciante do Valongo [...] achado morto na Rua Detraz do Hospício n.137, em frente a huma morada de cazas de sobrado com três janellas de frente...", como anuncia a transcrição de uma notícia (provavelmente) de época, e hoje um documento, na abertura do romance seguido do título impactante "O defunto mais estranho de São Sebastião" (p.7).

A trama, que conta com personagens históricos, como a cantora lírica Joaquina Lapinha e o livreiro Manoel Mandillo, desnuda o Rio de Janeiro de Dom João VI e todas as contradições que a Corte portuguesa acirrou na Colônia brasileira, a partir de sua vinda, em 1808. A famosa frase introdutória "Era nos tempos do rei", de certo sargento de milícias de Manuel Antônio de Almeida, ganha novo fôlego. Assim como aquele ar pitoresco de narrar o Brasil dá lugar à análise contundente de Eliana Cruz, cujo olhar sobre a História [nunca conhecida ou] contada não poupa os envolvidos em sua escrita.

O romance é dividido em seções e títulos que, aos poucos, oferecem pistas sobre o mistério e exigem a participação de um leitor atento e detentor de certa verve investigativa. Estratégia capaz de fisgar e estimular sua participação na trama cujo verdadeiro e maior crime é desvelado por meio das descrições dos atos cometidos durante o período em questão, a escravidão que ajudou a erigir o Brasil do século XIX e suas riquezas. As fontes consultadas, de acordo com as referências, ao final fornecidas, são a Gazeta do Rio de Janeiro e o Jornal do Commercio, entre o período de 1809 e 1835. 
A narração polifônica - alternada entre a moçambicana Muana e o mestiço nascido no Brasil, Nuno, - mistura-se também a personagens dos mundos real e sobrenatural. O insólito é incorporado à narração num requinte muito afeito às narrativas de Mia Couto, por exemplo, para citar um autor moçambicano que, em Terra sonâmbula (1992), também se vale de dois narradores para descrever os horrores - ali, na guerra civil - em meio a toda diversidade cultural africana. A autora, assim como sua personagem Muana, ao afirmar, em certo ponto do enredo, que "uma mulher do meu povoado jamais poderia deixar seus antepassados de lado", assume a incumbência de contar a história dos seus ancestrais africanos e sua importância na formação do Brasil.

Da mesma forma, Eliana Cruz apresenta as crenças africanas também no convívio de mundos complexos em manifestações. Sejam tais manifestações do ser ou fazer, ao ligar Moçambique e Brasil, até mesmo no encontro das águas - toda a natureza é testemunha - dos oceanos Indico e Atlântico como cenários e provas do horror das práticas desumanizadoras da escravidão.

A própria figura do comerciante Bernardo Lourenço é repugnante, condensando em si os desmandos, a crueldade e a perfídia de um homem de negócios enriquecido às custas de práticas escusas e condenáveis, de modo a retratar o perfil dos senhores de escravos abusadores sexuais e torturadores inatos. De fato, todas as mazelas impostas aos escravizados aparecem como ações naturalizadas na narrativa - visto que são pilares dessa sociedade - desde a saída de África até a vida no Brasil. Assim, ao mesclar inventividade a fatos históricos, a autora descreve o cotidiano carioca a partir da chegada da família real portuguesa, a organização da corte e o intenso fluxo de navios negreiros - os tumbeiros - no cais do Valongo, juntamente aos elementos bizarros por trás desse cotidiano. Eliana também estende a narrativa até a mudança de nome do estigmatizado Cais do Valongo para Cais da Imperatriz, mostrando as transformações ocorridas na capital do Império, intensificadas diante da iminente chegada de Teresa Cristina Bourbon-Duas Sicílias, a futura esposa de Dom Pedro II, que deveria ser mantida afastada do pernicioso tráfico de escravos, assim como toda a corte europeia.

No entanto, a desativação do cais do Valongo apresenta também a mudança do porto como medida estratégica, dado que o tráfico de africanos escravizados no Brasil seria intensificado, alcançando então diversos outros portos brasileiros - portanto, não só no Rio de Janeiro -, até a completa extinção do método por meio da Lei Áurea, em 1888, atendendo à pressão da Inglaterra - representada, na trama, por Mr. Toole.

Os relatos dos narradores Muana Lomué e Nuno Alcântara Moutinho concentram-se nos sofrimentos dos escravizados Tereza, Roza e Mariano - cada um deles representantes do continente africano em sua diversidade. Citam, até mesmo, curiosidades de famílias abastadas e tradicionais funcionando como uma espécie de microcosmo de toda a corte, como a da senhorinha Emerenciana Campelo D’Ávila. Numa estratégica narração iniciada em finis res, a autora mostra o Rio de Janeiro como grande personagem a acompanhar a trajetória de milhares de homens e mulheres cujos direitos foram completamente negligenciados por anos. Fator fundamental para compor, junto à sociedade brasileira, uma exclusão tão enraizada em todas as camadas de sua formação. Elemento ainda longe de ser superado. 
Ao descrever o Valongo, a autora assombra - em meio a fantasmas e gentes de outros mundos -, ao mostrar as divisões que perfazem o Brasil sobretudo na disposição de sua geografia. Cenas longamente descritas preenchem quase plasticamente o Rio daquela época ao dialogar com o Rio de hoje. De modo quase pictórico, também lembra uma gravura de Debret ou uma fotografia de Marc Ferrez. São corpóreas, tangíveis e horrendas as cenas propostas no romance. São, sem dúvida, corpos de homens, mulheres, escarpas, enseadas, cais, pedras, oceanos em ondas (tudo amalgamado) que aparecem diante dos leitores. Um desfile de sensações, cheiros, ruídos e incômodos que fariam gosto - e até inveja - a Aluísio Azevedo em seu cortiço.

"O Valongo não era nada bem visto. Ficava um tanto fora da cidade, que tinha uma costa com muitas enseadas e ilhotas repletas de trapiches e escritórios. A enorme Pedra do Sal nos separava do resto. Para chegar ao outro lado, eu tinha que dar uma volta enorme pelo morro da Conceição. Quase toda a casa aqui era também um depósito de gente...gente para venda." (p. 15)

No entanto, mostra-se ainda mais atual ao ser enfocada a Pedra do Sal, na região hoje ainda conhecida como Pequena África - segundo o batismo de Heitor dos Prazeres - em um Brasil segmentado a partir de marcas que ainda refletem o genocídio da escravidão estética e historicamente.

Recebido em: 11/01/2019

Aceito em: 28/08/2019 